\title{
MITHRAEA IN POETOVIO AND THE NEW DISCOVERY
}

\begin{abstract}
Summary: In the 2nd and 3rd centuries, Poetovio (modern town of Ptuj in north-eastern Slovenia) was a melting pot of various cultures due to the arrival of various peoples. Mithraea are undoubtedly the most recognisable monuments of Poetovio. As many as five or perhaps even seven Mithraea were discovered in Ptuj and its immediate surroundings: two of them (Breg na Ptuju, Hajdina) are preserved in situ, on the site where they were discovered. During the construction of the local sewage system in 2011, some findings that can be attributed to the Mithras cult were unearthed in the vicinity of the first Mithraeum in Spodnja Hajdina.
\end{abstract}

Key words: Poetovio, Vicus Fortunae, temple, birth, bull, customs official, Sol, sacrifice, fibula

Through the picturesque landscape between Haloze and Slovenske Gorice Hills in north-eastern Slovenia, the ancient Amber Road wound for centuries between the North Sea, the Po Valley and the Mediterranean Sea. At the crossings of the thennavigable Drava River, a series of settlements gradually appeared. The ancient town of Ptuj developed at the intersection of traffic roads, the prehistoric Amber Road, the Roman Road and the navigable Drava River which, in ancient times, connected the settlement with the Alpine area, the Central European area and the Pannonian area. ${ }^{1}$

Modern Ptuj, a small town in the northeast of Slovenia and on the edge of the Slovenske Gorice hills, boasts a distinctive layout of a medieval city. Both sides of the Drava River are rich in archaeological history; during the excavation works in

${ }^{1}$ PAHIČ, S.: Die Erforschung der Römerstrassen in Nordöstlichen Slowenien. Arheološki vestnik 34 (1983) 247-287; MIKL-CURK, I.: Petoviona v sožitju z bližnjimi in daljnimi kraji [Poetovio in Coexistence at Rome and Abroad]. Ptujski arheološki zbornik 1993, 205-218; VOMER GOJKOVIČ, M. - KOLAR, N.: Archaeologia Poetovionensis, Stara in nova arheološka spoznanja [Archaeologia Poetovionensis, Old and New Archaeological Discoveries]. Archaeologia Poetovionensis. Ptuj 1993; VOMER GoJKovič, M.: Poetovio - transportno-trgovački centar rimske provincije Panonije [Poetovio - the Transport and Trade Centre of the Roman Province Pannonia]. Histria Antiqua 12 (2004) 167-172. 
the town and its surroundings, numerous remains from different periods were discovered. $^{2}$

The advantageous position of Poetovio next to a passage across the Drava River has always been strategically important, starting with the arrival of the Romans who first stopped at the river and then pushed forward to the Pannonian plain and to the Danube River, and who established their headquarters in Poetovio at the beginning of the 1 st century.

Poetovio was first mentioned in the Historiae by Tacitus where he described the events in $69 \mathrm{AD}$, which had an impact on Poetovio's role and its importance as well as on its economic development. The Roman Poetovio, with the official name Colonia Ulpia Traiana Poetovio, reached the peak of its development in the 2 nd and 3rd centuries, when it became a large provincial town with important administrative government offices.

Poetovio was one of the biggest and most developed Pannonian towns, with seats of state offices. The town developed equally on both banks of the river Drava and had four distinctive quarters. One was located in Spodnja Hajdina, called Vicus Fortunae, where the main customs office Portorium publici Ilyrici was established. A quarter of urban villas was located in Zgornji Breg. On the left bank of the river Drava, below the Castle and Panorama hills, the administrative quarter expanded all the way to the stream of Grajena, and to the east of the same stream was the crafts quarter. $^{3}$

Among the population there were many immigrants, soldiers, clerks, merchants and custom officers, who brought different cultures and religions into the town. The world of antique religious faiths was very rich, variegated and subdivided. Under the influence of Greek culture, Romans took over their gods and adapted them to suit their needs. They worshiped various gods and deities, because every aspect of their lives had its divine protector. Temples were erected in every town quarter. ${ }^{4}$

Mithras temples or Mithraea are undoubtedly the most recognisable monuments of Poetovio. ${ }^{5}$ As many as five, some even speak of seven, Mithraea were discovered in Ptuj and its immediate surroundings: two of them (Breg na Ptuju, Hajdina) are preserved in situ, on the site where they were discovered.

\footnotetext{
${ }^{2}$ Vomer Gojkovič, M.: Quarters of Roman Poetovio (Building Complexes in Different Parts of Ptuj). Histria Antiqua 11 (2003) 221-228; Horvat, J. - LOVENJAK, M. - DOLENC VičIČ, A. - LuBŠINATUŠEK, M. - TOMANIČ-JEVREMOV, M. - ŠUBIC, Z.: Poetovio, Development and Topography. The Authonomous Towns of Noricum and Pannonia. Situla 41 (2003) 153-189; VOMER GOJKOVIČ, M.: Zgodovinski oris Petovione / Poetovio im historischen Überblick. Rimljani: steklo, glina, kamen [katalog razstav] = Die Römer: Glas, Ton, Stein [Austellungskatalog]. Celje-Maribor-Ptuj 2004, 86-89.

${ }^{3}$ VOMER GOJKOVIČ: Quarters (n. 2) 221-228; HORVAT ET AL. (n. 2) 153-189.

${ }^{4}$ Vomer GoJkOvič, M.: Die römischen Armee und die Religion. In 19th Congress of Roman Frontier Studies, Limes XIX (2006) 463-470.

5 ABRAMiĆ, M.: Poetovio, Führer durch die Denkmäler der römisches Stadt. Wien 1925, 63-79, 162-171, 172-190; CURK, I.: Ohranjeni mitreji na Slovenskem [Die in Slowenien erhaltenen Mithräen]. Kulturni in naravni spomeniki Slovenije 31. Maribor 1972; VOMER GOJKOVIČ, M.: Petovionski mitreji [Die Mithräen in Poetovio]. Archaeologia Poetovionensis 2 (2001) 105-124.
} 
Between 2010 and 2014, both temples were renovated. The area around the first temple, located in Hajdina, was rearranged and became easily accessible, while the third temple, in Breg, was renovated and electrified. New brochures were published at the same time.

In the trade-and-temples quarter, known as Vicus Fortunae in present Spodnja Hajdina, was discovered the first Mithraeum at the end of the 19th century. Twelve monuments were unearthed, among which two were of specific importance: a monument depicting Mithras' birth from the rock and a statue of Mithras carrying the bull, a scene which is rarely depicted. The latter bears an inscription about the restoration of the temple. All the stone monuments are made of white, eastern-Alpine marble. During the excavations the parts of the main altar which was supposedly located in the western wall of the temple were not found. The inscriptions on the monuments from the temple revealed that the majority of votive altars were erected by the Poetovio customs officials in the middle of the 2 nd century. The Mithraeum was probably used until the 4 th century. ${ }^{6}$ The temple was the first in Pannonia, and though one of the smallest, measuring approximately $7 \times 7 \mathrm{~m}$, it represented a great discovery as it is one of the oldest. The typical temple building is square ground-plan and, supposedly had a wooden vault. It has a narrow oblong room in front of the entrance and a small room to the side of it, supposedly a treasure room. In its architecture and furnishing, the first Mithraeum is one of the most beautifully preserved examples of an "ideal" Mithraeum, strictly depending on the Mithraic conception of the universe as it is known thanks to Porphyry. This universe is holistic, dynamic and harmonious, built on complementary opposites. Its creator and master is Mithras (fig. 1). The Mithraeum is visible on the site and sheltered by protective building.

The first Mithraeum represents an exquisite cultural heritage; consequently it has been proclaimed a monument of national importance. The protective building was renovated in 1999, on the hundredth anniversary of the discovery. In 2010 the PtujOrmož Regional Museum carried out protective procedures on monuments and remnants of Roman architecture (fig. 2).

The second Mithraeum was discovered in 1901, some 20 metres south of the first one. It was also mostly built by customs officials some 50 years after the first Mithraeum, and it must have been in use until the mid-4th century. ${ }^{7}$

In Poetovio's Mithraea, the main altar panels are not fully preserved; for this reason, the altar reliefs from the second Mithraeum are important, dated between the end of the 2 nd and the beginning of the 3 rd centuries. At the bottom of the edge of the best-preserved votive relief - a two-line inscription mentions a soldier of Legion II Italica, Licinius Maximinus, who fulfilled a promise to the invincible god Mithras.

${ }^{6}$ ABramić (n. 5) 162-171. HofFILler, V. - SARIA, B.: Antike Inschriften aus Jugoslavien. Heft I: Noricum und Pannonia Superior. Zagreb 1938, 133-139; VOMER GOJKOVIČ, M. - DJURIĆ, B. - LOVENJAK, M.: Prvi petovionski mitrej na Spodnji Hajdini [First Mithraeum from Poetovio in Spodnja Hajdina]. Pokrajinski muzej Ptuj-Ormož 2011.

${ }^{7}$ ABRAMiĆ (n. 5) 63-79; VOMER GOJKOviČ: Petovionski mitreji (n. 5) 105-124; VOMER GOJKOVIČ ET AL. (n. 6). 


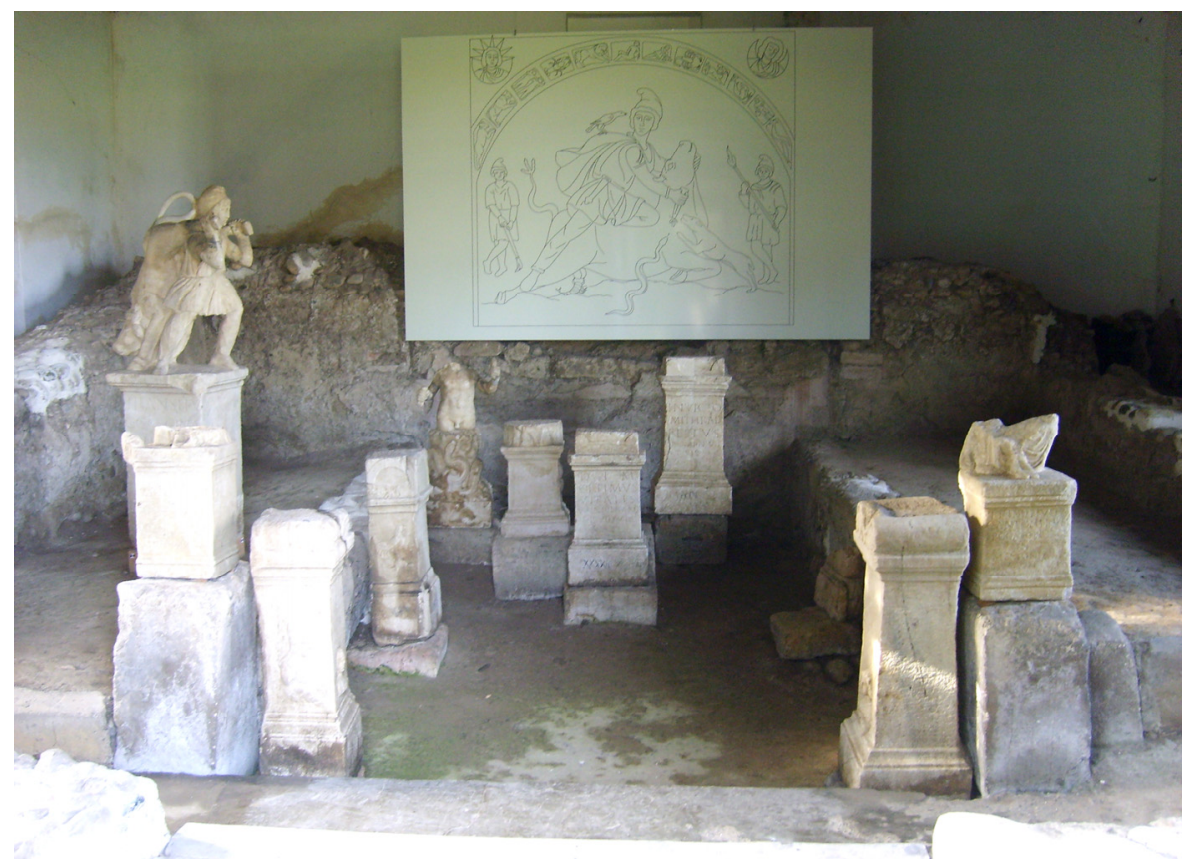

Fig. 1. Mithras Shrine I, the inside (photo by M. Vomer Gojkovič)

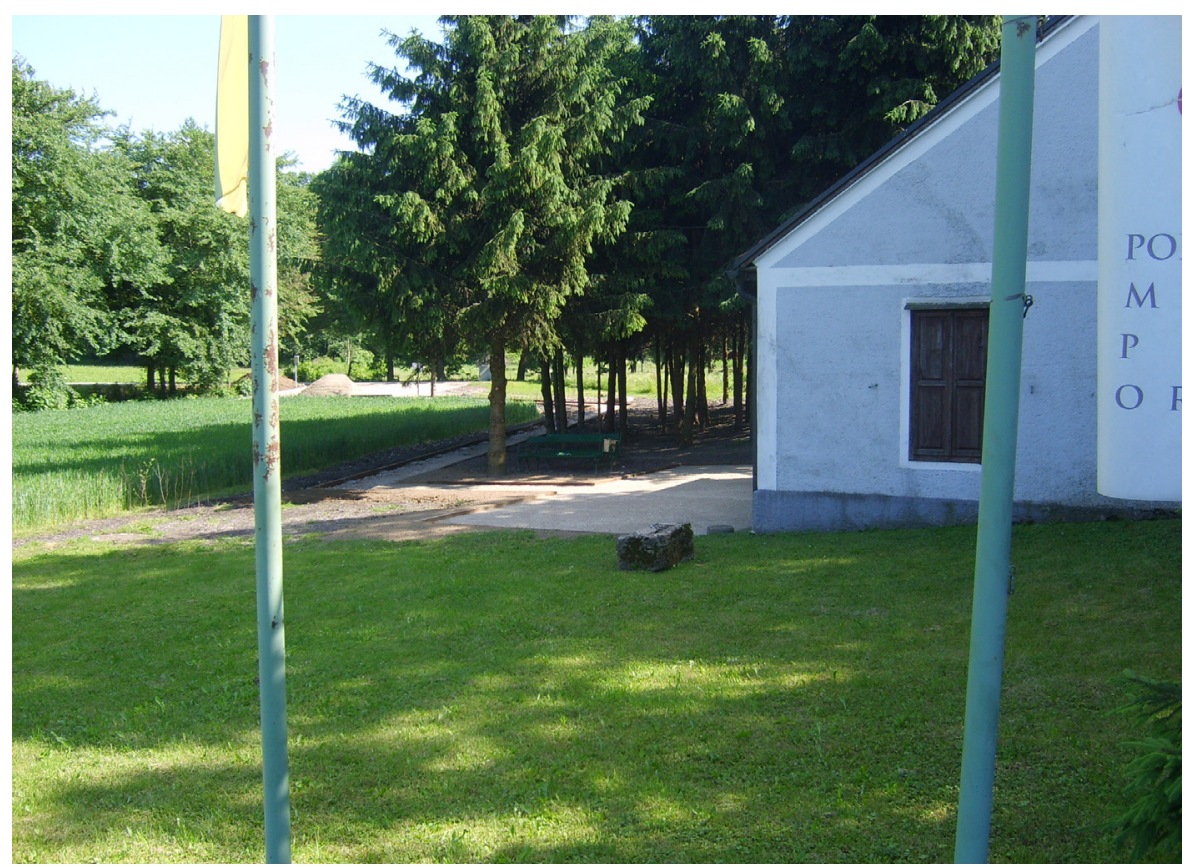

Fig. 2. Mithras Shrine I, surroundings (photo by M. Vomer Gojkovič) 


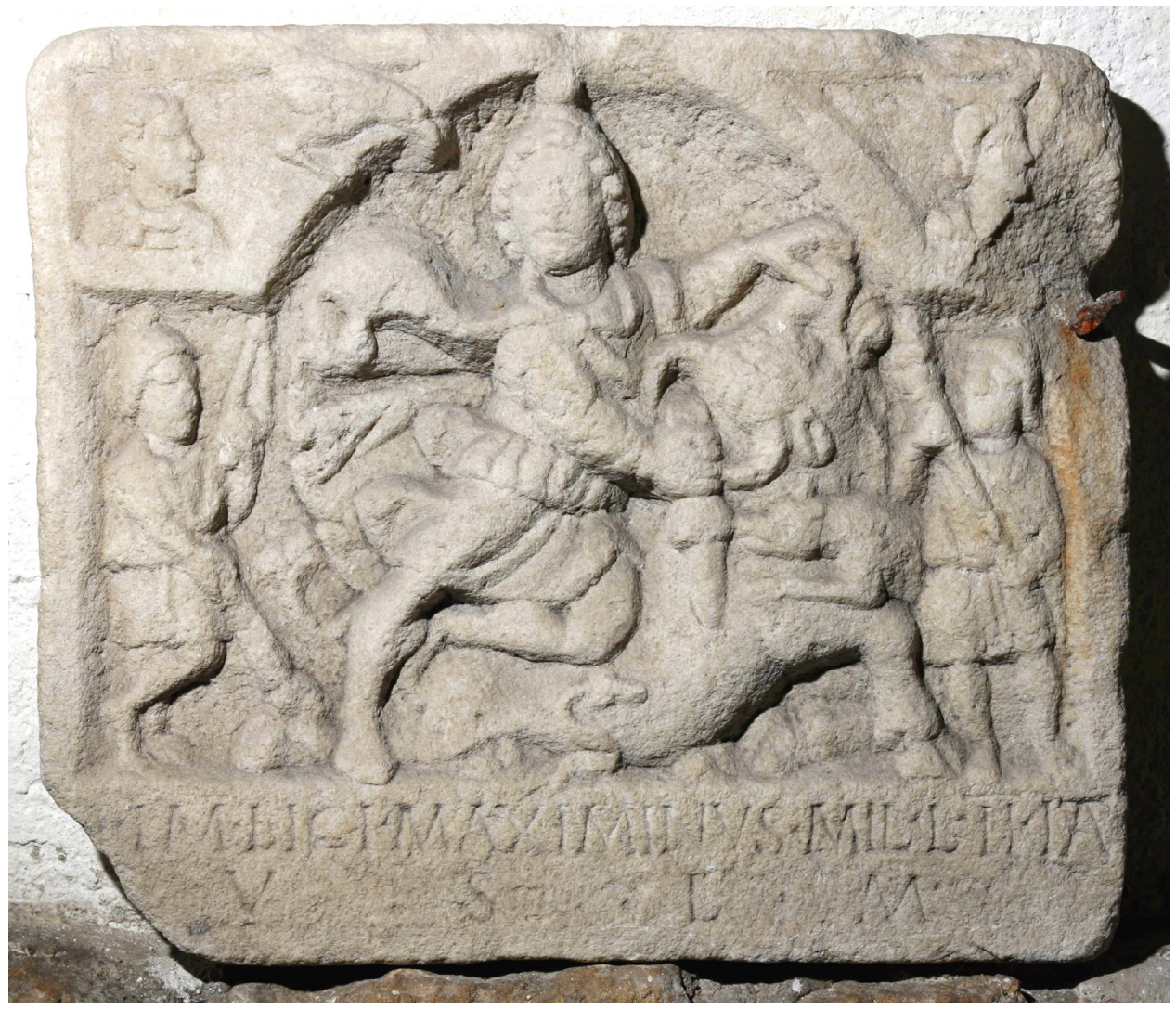

Fig. 3. Mithras sacrificing a bull, side altar plate from the Mithras Shrine II (photo by B. Farič, Ptuj Ormož Regional Museum)

The relief shows the cave where Mithras slaughtered the bull; left and right are Cautes and Cautopates and, in the upper corners, the busts of Sol and Luna (fig. 3). ${ }^{8}$

The third Mithraeum is the largest among the temples found in Poetovio. ${ }^{9}$ The excavation works in the area ended in September 1913. The temple was oriented with almost perfect precision from north to south; the southern side was partly built into a small ground elevation and clearly shows two building stages. The temple measures $16 \times 8 \mathrm{~m}$, and is divided into three naves: the central one was deepened and its soil was paved with bricks, while on both sides, naves were separated from the central one by a small stone wall, elevated and covered with packed clay. The interior was coated with simple wall paintings. Pieces of clay coating bearing marks of intertwined willow (n. 5) 105-124.

${ }^{8}$ ABRAMiĆ (n. 5) 76; HOFFILlER-SARIA (n. 6) 139-144; VOMER GOJKOVIČ: Petovionski mitreji

${ }^{9}$ ABRAMIĆ (n. 5) 172-190; HOFFILlER-SARIA (n. 6) 144-150; VOMER GOJKOVIČ: Petovionski mitreji (n. 5) 105-124; M. VOMER GOJKOVIČ: Tretji petovionski mitrej [Third Mithraeum in Poetovio]. Ptuj 2014. 


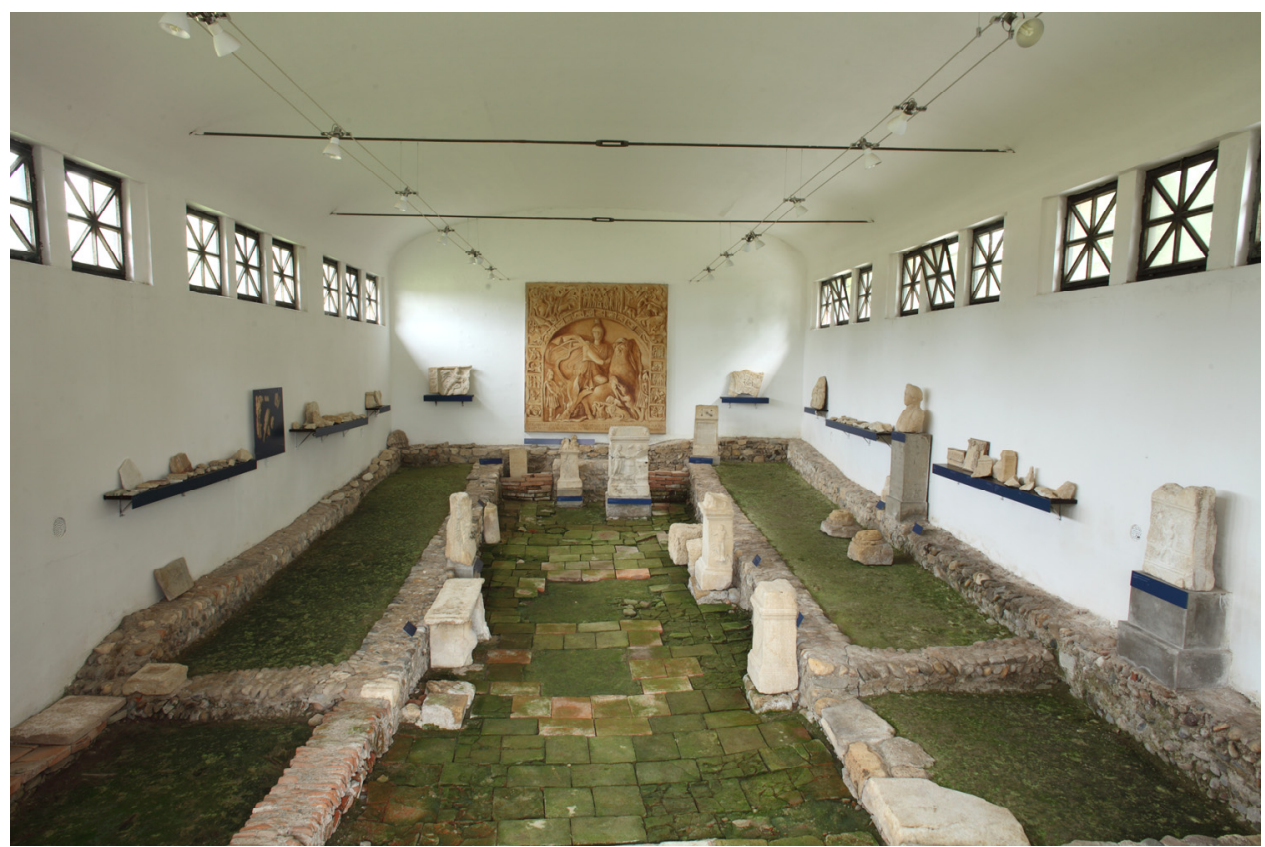

Fig. 4. Mithras Shrine III, the inside (photo by B. Farič, Ptuj Ormož Regional Museum)

branches, suggesting that the temple was built imitating the form of a cave and was most probably covered by a roof. On the western side, a small channel was dug into the ground to convey water which was needed during rituals (fig. 4).

Dedications belonging to the last building phase of the third Mithraeum were mostly commissioned by soldiers of legions V Macedonica and XIII Gemina, to ask for their own and the Emperor Gallienus's prosperity, thus proving that in the 60s of the 3rd century an important military division was present in Poetovio and led by the commander Flavius Aper. The temple was still in use in the first decades of the 4th century. As the remains of the building were rather well preserved, it was decided to leave them on the site of discovery. ${ }^{10}$

Along with the remains of the third Mithraeum, one can also see some badly weathered votive stones brought from the small Mithraeum in Modrič in Pohorje, a quarry from where the Romans got the white marble. ${ }^{11}$

Another major discovery occurred in 1957 in the administrative part of Roman Poetovio. ${ }^{12}$ On Muzejski Trg 1 (Museum Square 1), within the curve around the Castle hill, at a depth of $1.4 \mathrm{~m}$, many horizontally positioned marble blocks in a secondary

${ }^{10}$ Abramić (n. 5) 172-190; Hoffiller-SARIA (n. 6) 144-150; VOMER GOJKOviČ: Die römischen Armee (n. 4) 463-470; VOMER GOJKOVIČ (n. 9).

${ }^{11}$ ABRAMIĆ (n. 5) 193. VOMER GOJKOVIČ: Tretji petovionski mitrej (n. 9) 39-46.

${ }^{12}$ MiKL, I.: Petovijski četrti mitrej [Fourth Mithraeum from Poetovio]. Ptujski zbornik 2 (1962) 212-218. VOMER GOJKOVIČ: Petovionski mitreji (n. 5) 105-124. 


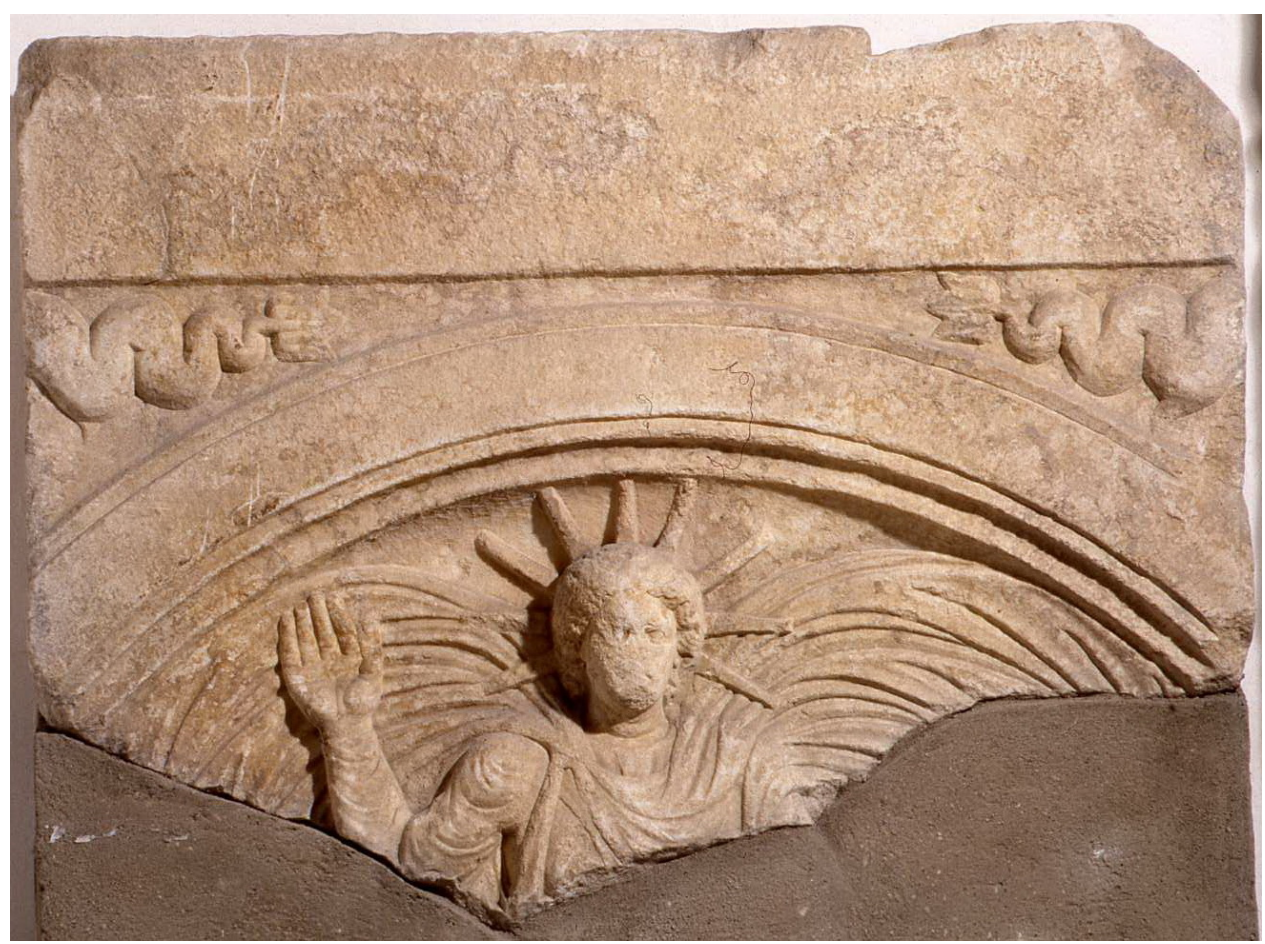

Fig. 5. Sol, altar plate from the Mithras Shrine IV (photo by B. Farič, Ptuj Ormož Regional Museum)

position, which constituted part of the pavement and roads; among them was a relief with the depiction of Sol (fig. 5).

The upper part of the panel is flat. Under the profiled arch the bust of the Sungod is depicted; he is shown as a barefaced young man with gentle and mild facial features, with curly hair and a crown of nine rays on his head and his right hand raised with stretched fingers. The mantle of Sol is fluttering, and on the right shoulder it is tied together with a round buckle; his clothing with long sleeves is wrinkled. Under the wide edge there are two hippocampuses and their bodies continue on to other panels adjacent to the main one. Behind, the relief is practically destroyed with the traces of wheel ruts. According to the iconography, the style of this Mithraic relief suggests a date within the reign of Gallienus. ${ }^{13}$ Among the monuments belonging to the fourth Mithraeum, the most important one is telling us that the temple of the invincible Mithras was destroyed and subsequently renewed by Aurelius Iustinianus, a military commander of noble birth. Hence, it can be deduced that, in general, high ranking military commanders would follow the emperor's policy and would reconstruct Mithraea. $^{14}$

\footnotetext{
${ }^{13}$ MikL (n. 12) 212-218; JeVremov, B.: Vodnik po lapidariju [Guide to Lapidaries]. Ptuj 1988, $75-76$

${ }^{14}$ MiKL (n. 12) 212-218.
} 
Monuments from a Mithraeum were also found in 1965 at Vičava, including two fragments of decorated reliefs dedicated to Mithras (left upper corner with Sol and Cautopates and the left lower corner of the inscription dedicated to Mithras). ${ }^{15}$

The richness of the archaeological heritage of Roman Poetovio has been implemented by an important finding in $1987 .{ }^{16}$ A discovery of the fifth Mithraeum, in the vicinity of Student Dormitory (Dijaški dom), proves a developed spiritual life even in Poetovio's crafts quarter. Among the remains of two badly preserved wall foundations of river pebbles, parts of the marble altars have been discovered, as well as parts of the fluted and smoothly treated pillars, parts of a relief with a depiction of Cautes and Cautopates, a head of Mithras, a relief depicting the Mithraic tauroctony, a relief of Sol and Luna, and an altar of yellow sandstone. The fifth Mithraeum was in use from the 3 rd to the mid-4th century. ${ }^{17}$

During excavations for the local sewage system in 2011 , in the vicinity of the first Mithraeum in Spodnja Hajdina, some findings were brought to light that can be ascribed to the Mithras cult. The most important among them is a bronze fibula (figs 6-9). ${ }^{18}$ These finds include a zoomorphic brooch, a fibula with a bow in the form of a fully plastic figure of a bronze jumping lion sized $2.8 \times 1.72 \mathrm{~cm}$. The hind paws of the lion are joined to the head of the brooch with a mechanism for coupling, and the forepaws continue with an elongated trapezoidal quadrilateral catch plate where the pin rests. The pin is attached to the hinge between the hind lion's paws. The lion holds between the front paws an elongated tray, decorated with parallel grooves. On the plate is a bull's head sized $0.75 \times 0.7 \mathrm{~cm}$. The bull's head is fixed on the fibula between lion's paws by means of a rivet passing through a round opening with a diameter of $0.47 \mathrm{~cm}$ (fig. 10).

Fibulae with a bow in the form of a lion in the Slovenian area are rare; there are only four examples from Rihemberk in Branik, ${ }^{19}$ from Most na Soči, and two from Savinja in Celje, which can be dated to the beginning of the 1st century. In Croatia a similar brooch was found on the site Novi Banovci and it is kept in Zagreb in the Archaeological Museum (inv. No. 305). ${ }^{20}$ A similar fibula, but without the bull's head, was found in Sisak (inv. No. 3458); both fibulas are $3 \mathrm{~cm}$ long. ${ }^{21}$ The addition of the bull's head to the fibula from Hajdina may be ascribed to the Mithraists and

15 ŠUBIC, Z.: Ptuj, Vičava. Varstvo spomenikov 10 (1965) 203. ŠUBIC, Z.: Epigrafske najdbe v Ptuju in območju v letih (1963-1966) [Epigraphische Neufunde aus Poetovio und Umgebung (1963-1966)]. Arheološki vestnik 18 (1967) 212-192.

${ }^{16}$ TUŠEK, I.: Peti mitrej v Ptuju [Das fünfte Mithräum in Ptuj]. Arheološki vestnik 41 (1990) 267276; TUŠEK, I.: Peti mitrej na Ptuju [V. Mithräum in Ptuj]. Archaeologia Poetovionensis 2 (2001) 191215; VOMER GOJKOVIČ: Petovionski mitreji (n. 5) 105-124.

${ }^{17}$ TUŠEK 1990 (n. 16) 267-276; TUŠEK 2001 (n. 16) 191-215. publish.

${ }^{18}$ Excavations Ptuj - Ormož Regional Museum led Ivan Žižek, whom I thank for permission to

${ }^{19}$ BAVDEK, A. - CUNJA, R. ET AL.: S fibulo v fabulo : fibule iz Istre, s Krasa, iz Notranjske in Posočja med prazgodovino in zgodnjim srednjim vekom = Con la fibula nella storia : fibule dall'Istria, dal Carso, dalla Carniola Interna e dall'Isontino tra preistoria e alto medioevo. Koper 2010, 56.

${ }^{20}$ KOŠČEVIĆ, R.: Antičke fibule s područja Siska [Roman Fibulae from Siscia]. Zagreb 1980, 31.

${ }^{21}$ KOŠČEVIĆ (n. 20) 31, 83, 106. 


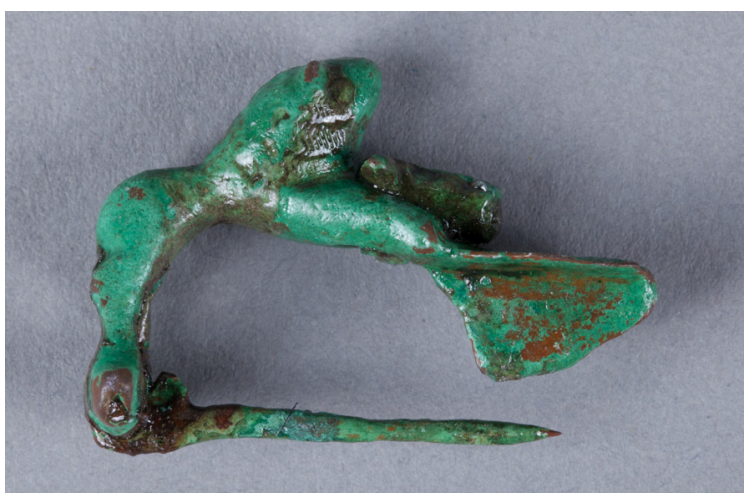

Fig. 6. Zoomorphic fibula

(photo by B. Farič, Ptuj Ormož Regional Museum)

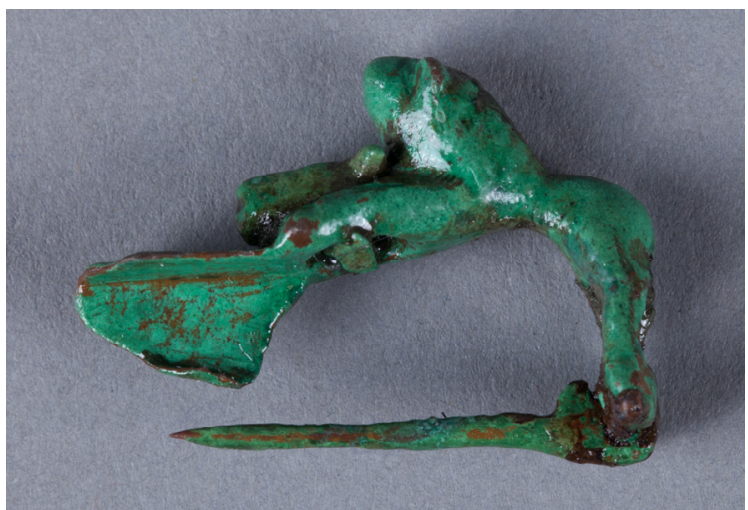

Fig. 7. Brooch in the form of a lion in a jump (photo by B. Farič, Ptuj Ormož Regional Museum)

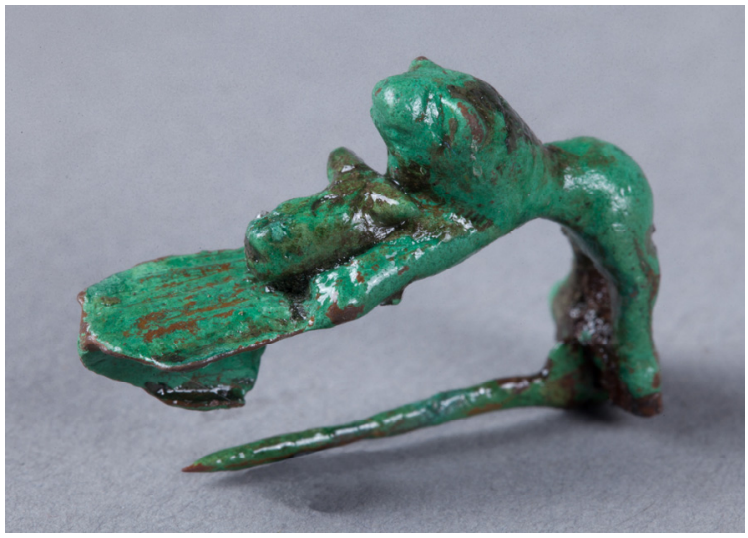

Fig. 8. Zoomorphic fibula, detail (photo by B. Farič, Ptuj Ormož Regional Museum) 


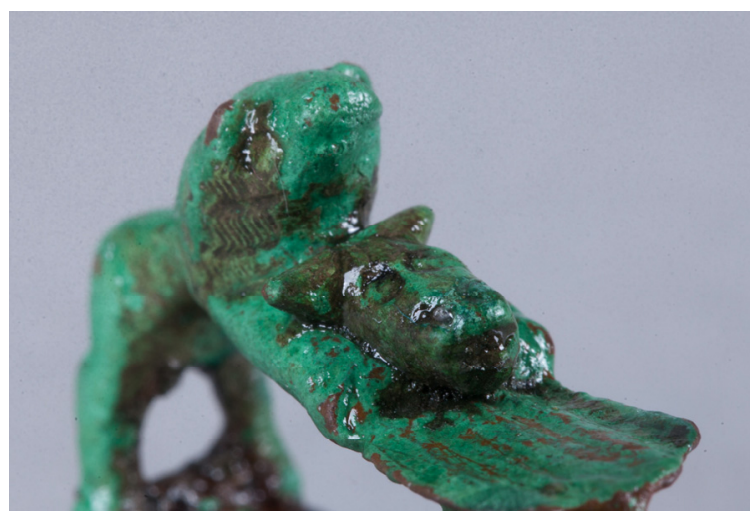

Fig. 9. Zoomorphic fibula, detail with the bull (photo by B. Farič, Ptuj Ormož Regional Museum)

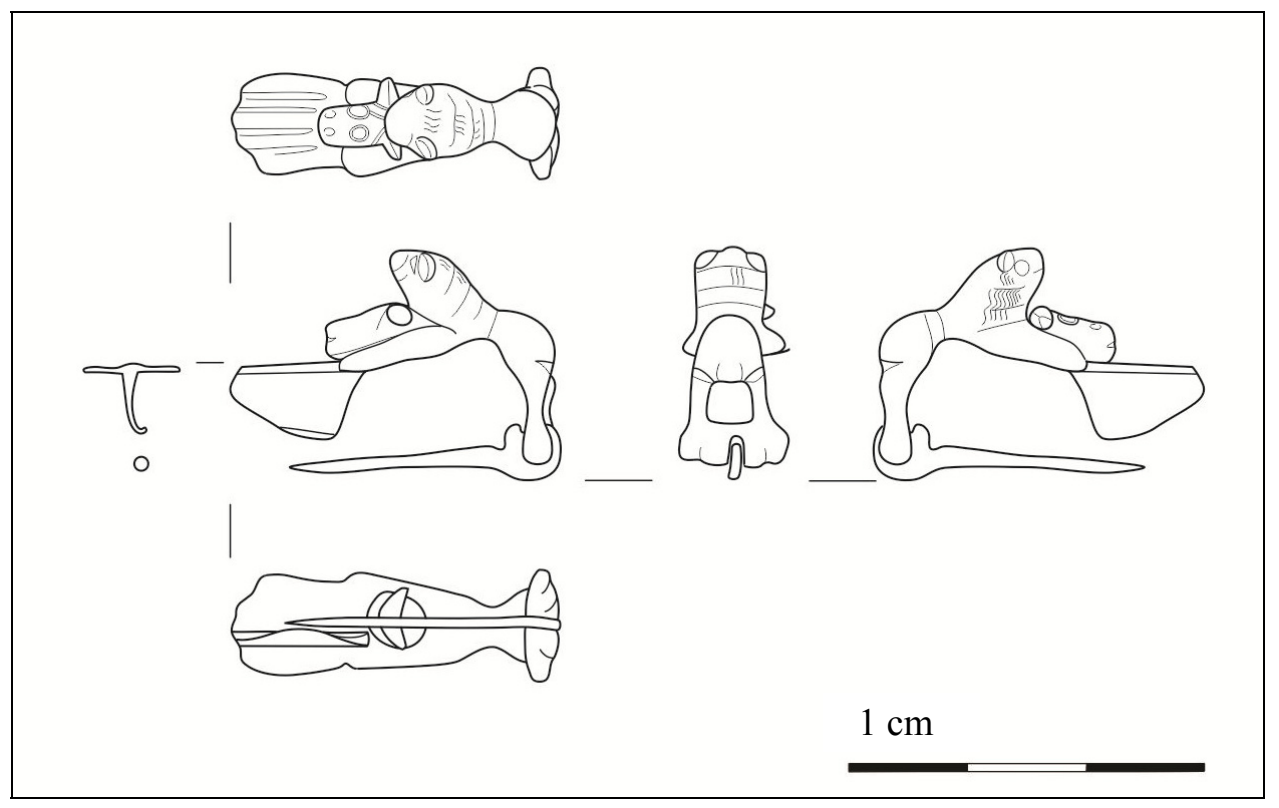

Fig. 10. Brooch in the form of a lion in a jump (drawing by N. Uršič, Ptuj Ormož Regional Museum)

dated to the 2nd century, which is the lifetime of the first Mithraeum in that immediate vicinity.

Together with soldiers, craftsmen came to Poetovio bringing different cultures, habits, and customs. The residents of Poetovio became acquainted with them and included the new knowledge and skills into their everyday life, and Mithraism was among these cultural and religious imports. 


\section{CONCLUSION}

The renowned Mithraea from Poetovio are five, although some speak of seven; all of them were discovered in Ptuj and its immediate surroundings. All of them were functioning in the period from the 2 nd to the 4 th century. A great number of small items has been discovered inside and around the Mithraea; the majority of items is made of stone and pottery. Different types of vessels include jugs with handles and a snake coiling around it. Metal findings are fewer, but the majority of these were found near the third temple which, according to its content, belonged to the military. The first temple yielded the least items, only a few pottery fragments and a bronze statuette of a crow. Therefore, a fibula or brooch with a lion and a bull's head found near the temple represents an important finding and at the same time confirms the 2nd century as the time of the temple's construction.

Mojca Vomer Gojkovič

Pokrajinski muzej Ptuj-Ormož / Ptuj-Ormož Regional Museum

Slovenia

mojca.vomer-gojkovic@guest.arnes.si 
